Sharif University of Technology
Scientia Iranica
Transactions A: Civil Engineering
SCIENTIA
IRAN ICA

Research Note

\title{
A new approach to improving durability of rice husk ash blended concrete with re-dispersible polymer powder
}

\author{
D.K. Bangwar*, A. Saand, M.A. Keerio, and M.A. Zardari \\ Department of Civil Engineering, Quaid-e-Awam University of Engineering, Science \& Technology, Nawabshah, Sindh, Pakistan.
}

Received 3 March 2017; received in revised form 15 October 2017; accepted 22 October 2018

KEYWORDS
Durability;
Polymer;
RHA;
RHAPMC;
Permeability;
Water absorption;
Ultrasonic pulse
velocity.

\section{ORDS}

Polymer;

RHA;

velocity.

\begin{abstract}
An experimental investigation was conducted to improve the limitation of Rice Husk Ash (RHA) blended concrete in terms of durability by incorporating re-dispersible polymer powder. To investigate the durability properties of Rice Husk Ash PolymerModified Concrete (RHAPMC) matrix, the RHAPMC mix of 1:2:3 proportions was used to prepare specimens. To prepare Rice Husk Ash-Modified Mix (RHAMM), 10\% of RHA was replaced with cement. RHAPMC was made with the inclusion of polymer at a ratio of 1 to $7.5 \%$ by the weight of cement. The most common durability-related properties including water absorption, density, water permeability, ultrasonic pulse velocity, and compressive strength were experimentally investigated. The results showed a remarkable improvement in durability characteristics in the newly developed matrix of RHAPMC, which could be used as a repair material in an aggressive environment.
\end{abstract}

(C) 2020 Sharif University of Technology. All rights reserved.

\section{Introduction}

Efforts are made to utilize waste materials, produced from various sources, as a supplementary cementing material in the construction industry to reduce environmental problems. Rice Husk Ash (RHA) is one of such waste materials, which is obtained as an agrarian by-product of rice crop. RHA could be used as a source of supplementary cementing material in cement concrete and cement mortar. In the U.S., RHA is successfully registered by the trade name Agrosilica,

*. Corresponding author. Tel.: +92 3337016912

E-mail addresses: daddan@quest.edu.pk (D.K. Bangwar);

abdullah@quest.edu.pk (A. Saand);

mantharali99@quest.edu.pk (M.A. Keerio);

muhammad.auchar@quest.edu.pk (M.A. Zardari)

doi: $10.24200 /$ sci. 2018.21079 which gives excellent pozzolanic property [1]. In case of $10 \%$ cement replacement, the workability and permeability of concrete greatly improved and decreased, respectively [1]. Almost 600 million tonnes of rice generates about 20 million tonnes of RHA annually [2]. In Pakistan, rice is considered one of the cash crops and its cultivation comprised around 6.64 million tonnes in 2016/2017, which can cause a huge amount of waste material in the form of husk [3].

Rice husk is composed of mainly silica and carbon and has $\mathrm{SiO}_{2}$ from 90.02 to 96.71 wt\% and carbon from 2.18 and $8.63 \mathrm{wt} \%$ [4,5]. Nearly $200 \mathrm{~kg}$ of husk is obtained from every one tonne of pulverized paddy, and about $25 \%$ of RHA is yielded upon burning [2]. Extracting non-crystalline silica from the husk involves proper burning [6]. RHA particles are porous and characterized by a honeycombed microstructure [7]; as a result, the specific surface area of RHA is enormously 
high, which is 50 to $100 \mathrm{~m}^{2} / \mathrm{g}$ for amorphous RHA [8]. Consequently, mechanical and durability properties of concrete (i.e., water penetration, water absorption, ultra-pulse velocity, and density) and mortar are greatly affected. Extra fineness of RHA is required in order to achieve the maximum compressive strength of RHA-blended concrete. Habeeb and Mahmud [9] increased the fineness of RHA and concluded that fined RHA blended concrete gained more strength than coarse RHA and normal concrete. However, attaining ultra-fine RHA requires extra efforts in terms of cost and time. In addition, permeability is considered to be as important as compressive strength of cement concrete and mortar. The addition of much water as per more RHA demand in concrete can result in porous medium in RHA blended concrete and mortar. The permeability of hydrated cement paste is by and large a function of capillary porosity.

Polymer is an additive that is being used throughout the world to improve the mechanical and durability properties of concretes, mortars, and composites [10]. The inclusion of polymeric compounds in mortars and concretes may or may not have a significant effect on compressive strength [11-13]; however, it has a significant impact on the permeability of cement concrete and mortar. Ramli and Tabassi [14] concluded that incorporating $15 \%$ of polymer latexes could enhance the inbred properties of ordinary cement mortar by approximately 4 to 5 times.

In this paper, an attempt is made to introduce an entirely new technique for improving the durability property of RHA blended concrete by using redispersible polymer powder instead of making ultrafineness of RHA. In this approach, the pores of RHA blended concrete are blocked due to film-forming ability of polymer, resulting in the improved properties of the newly developed composite. To the best of authors' knowledge, no such composite is presented in the literature.

\section{Materials and methods}

\subsection{Materials}

In this study, ordinary Portland cement was used. For making concrete, fine and coarse aggregates with maximum sizes of $4.75 \mathrm{~mm}$ and $19 \mathrm{~mm}$ have been used, respectively. In RHA blended concrete, $10 \%$ of cement was replaced with the extracted RHA. Specific gravity and Blaine fineness were found to be 2.05 and $2251\left(\mathrm{~cm}^{2} / \mathrm{g}\right)$, respectively. The chemical composition of RHA is shown in Table 1.

In this study, the re-dispersible polymer powder, VINNAPAS $5044 \mathrm{~N}$, produced by Wacker was used as a cement modifier. It is white powder in appearance. It has a unit weight of $550 \mathrm{~kg} / \mathrm{m}^{3}$ and its particle size is $4 \%$ retained on $400 \mu \mathrm{m}$. It alters the basic
Table 1. Chemical properties of Rice Husk Ash (RHA).

\begin{tabular}{ccccccc}
\hline \multicolumn{6}{c}{ Elements of RHA (\%) } \\
\hline $\mathrm{SiO}_{\mathbf{2}}$ & $\mathbf{A l}_{\mathbf{2}} \mathbf{O}_{\mathbf{3}}$ & $\mathrm{Fe}_{\mathbf{2}} \mathrm{O}_{\mathbf{3}}$ & $\mathrm{CaO}$ & $\mathbf{M g O}$ & $\mathbf{K}_{\mathbf{2}} \mathrm{O}$ & $\mathbf{L O I}$ \\
\hline 91.74 & 1.12 & 0.98 & 0.81 & 2.18 & 0.00 & 1.50 \\
\hline
\end{tabular}

chemistry of cement by emulsification. The peramin sulfonated melamine formaldehyde has been utilized as a plasticizer to enhance the workability of concrete. Silicon dioxide in RHA, as shown in Table 1, is $91.74 \%$ which meets the requirement as pozzolanic material as per ASTM 618-03. The authors are of the view that RHA Polymer-Modified Concrete (RHAPMC) presented in this study is a newly developed composite.

\subsection{Experimental program}

\subsubsection{Concrete mix}

A concrete mix design having a characteristic strength of $26 \mathrm{MPa}$ was used to check the concrete durability in terms of resistance against water penetration, water absorption, and its qualitative characteristics. A ratio of $1: 2: 3$ in the slump range of 25 to $50 \mathrm{~mm}$ was used to investigate the durability properties of RHAPMC. For studying durability aspects, concrete mix was prepared, i.e., Control Mix (CM); 10\% RHA was replaced by cement in Rice Husk Ash-Modified Mix (RHAMM) and Rice Husk Ash Polymer-Modified Concrete mix (RHAPMM1-RHAPMM7.5) with the inclusion of polymer at a ratio of 1 to $7.5 \%$ by the weight of cement, as shown in Table 2. Of note, when $10 \%$ of cement was replaced with RHA, the compressive and tensile strength of the mix was found equal to that of the CM. Given $10 \%$ replacement of cement with RHA and the addition of $7.5 \%$ dosage of Redispersible Polymer Powder (RPP), the slump of control mix is 30,26 , and $37 \mathrm{~mm}$, respectively.

\subsubsection{Ultrasonic Pulse Velocity}

To determine Ultrasonic Pulse Velocity (UPV), a total of 30 cubes sized $100 \times 100 \times 100 \mathrm{~mm}$ were cast using mix design and, then, de-molded after 24 hours. The CM (un-modified) and RHAMC samples were cured for 28 days in moist curing as per ASTM C 192 [15] and polymer-modified concrete samples were first kept in wet curing for 7 days and, then, air dried for 21 days for curing as per JIS A 1171-2000 [16]. UPV of each specimen was determined using Ultrasonic NonDestructive Digital Indicating Tester (Pundit) [17].

\subsubsection{Density and water absorption}

To evaluate the density and water absorption capacity of the mix, cylindrical concrete samples of size $150 \times 300$ $\mathrm{mm}$ were cast to determine the density of each mix. After de-molding, all the specimens were prepared, de-molded, and cured, as specified in Section 2.2.2. Density and water absorption of each specimen were 
Table 2. Concrete mix design of Control Mix (CM), Rice Husk Ash Modified Mix (RHAMM), and Rice Husk Ash Polymer Modified Concrete (RHAPMM) as per ACI211.1-91.

\begin{tabular}{cccccccccc}
\hline Serial no. Concrete $\mathbf{m i x}$ & $\begin{array}{c}\text { Cement } \\
\left(\mathbf{k g} / \mathbf{m}^{\mathbf{3}}\right)\end{array}$ & $\begin{array}{c}\text { RHA } \\
\left(\mathbf{k g} / \mathbf{m}^{\mathbf{3}}\right)\end{array}$ & $\begin{array}{c}\mathbf{R P P} \\
\left(\mathbf{k g} / \mathbf{m}^{\mathbf{3}}\right)\end{array}$ & $\begin{array}{c}\text { Total binder Plasticizer } \\
\left(\mathbf{k g} / \mathbf{m}^{\mathbf{3}}\right)\end{array}$ & $\begin{array}{c}\text { Water } \\
\left(\mathbf{k g} / \mathbf{m}^{\mathbf{3}}\right)\end{array}$ & $\begin{array}{c}\text { F.A } \\
\left(\mathbf{k g} / \mathbf{m}^{\mathbf{3}}\right)\end{array}$ & $\begin{array}{c}\text { C.A } \\
\left(\mathbf{k g} / \mathbf{m}^{\mathbf{3}}\right)\end{array}$ \\
\hline $\mathbf{( \mathbf { k g } / \mathbf { m } ^ { \mathbf { 3 } } )}$
\end{tabular}

Note: Average of five specimens was taken. CM: Control Mix; RHAMM: Rice Husk Ash-Modified Mix; RHAPMM1 to

7.5: Rice Husk Ash Polymer Modified Mix (i.e., incorporation of redispersible polymer powder from 1 to $7.5 \%$ by

the weight of cement).

determined as per ASTM C1754 [18] and ASTM C1585 [19] standards, respectively.

\subsubsection{Water penetration}

Specimens were prepared, de-molded, and cured, as previously shown in Section 2.2.2. Water pressure of $0.5 \mathrm{MPa}$ was applied for 72 hours, as specified in BS EN 12390-8 [20]. After subjecting the required water pressure, the specimens were split into two halves and water-penetrated moistened surface measured as water penetration depth.

\subsubsection{Compressive strength}

Cylindrical specimens of size $150 \times 300 \mathrm{~mm}$ were cast and kept in curing tank for curing. The CM (unmodified) and Rice Husk Ash-Modified Concrete Mix samples were cured for 28 days in moist curing as per ASTM C-192 [15], and Polymer Modified Concrete Mix samples were first kept in wet curing for 7 days and, then, air dried for 21 days for curing as per JIS A1171-2000 [16].

\section{Results and discussion}

\subsection{Ultrasonic Pulse Velocity (UPV)}

UPV is an additional, imperative characteristic of concrete that represents its porosity and density. In order to verify the taxonomy of RHA, Scanning Electron Microscopy (SEM) was performed. The SEM results obtained at various resolutions showed that the RHA was multifaceted and angular with micro absorbent surface and, also, was characterized by high specific surface, as shown in Figure 1(a)-(e).

The UPVs of CM, RHA modified at $10 \%$ cement replacement mix, and RHAPMC with the incorporation of polymer from $1-7.5 \%$ were determined in 28 days. As shown in Figure 2, the UPV of RHAMM is less than that of the CM. The decreasing trend of UPV in RHAMM illustrates that the quality of RHAMM in terms of porosity is affected by the addition of RHA. As shown in Figure 2, with the addition of
RPP in RHAMM, an improving trend in UPV has been observed because of the pore-filling ability of the polymer. The increased ultrasonic velocity of RHAPMC reveals that cracks are sealed and blocked by polymers, thus improving the quality of concrete more than that of RHA blended concrete. From the results, UPV of the RHAPMC ranges from 4.24 to $4.26 \mathrm{~mm} / \mu \mathrm{s}$ which falls within the prescribed limit of medium to excellent quality $(3.660-4.575 \mathrm{~mm} / \mu \mathrm{s})$ [21]. Based on the provided range, RHAPMC falls in the excellent quality of concrete.

\subsection{Density}

Given the $10 \%$ cement replacement with RHAMM and RHAPMM by incorporating polymer from 1 to $7.5 \%$, densities of the CM were determined in 28 days. As shown in Figure 3, the density of RHAMM is less than that of the CM. The decreased density of RHAMM mainly results from the low specific gravity of the ash. As shown in Figure 3, the inclusion of RPP in the RHA-blended concrete causes a further reduction in the densities of rice husk ash polymer-modified mixes because of air entrapping characteristics of the polymer from the environment; these findings are validated in [22]. It is found that the density of RHA polymermodified specimens ranges from 2377.92 to 2406.23 $\mathrm{kg} / \mathrm{m}^{3}$, which comes within the limit of density of normal concrete [23].

A comparison is made between the UPV and densities of the mixes, the results of which are shown in Figure 3. While the density of RHAPMC is decreasing, the quality of concrete has improved in terms of UPV because of the sealing of pores by the polymer.

\subsection{Water absorption}

Water absorption results of all mixes are shown in Figure 4 . The figure shows that the water absorption capacity of the $10 \%$ cement replaced concrete (i.e., RHAMM) increases with respect to the CM because of the following reasons. The first reason is the 


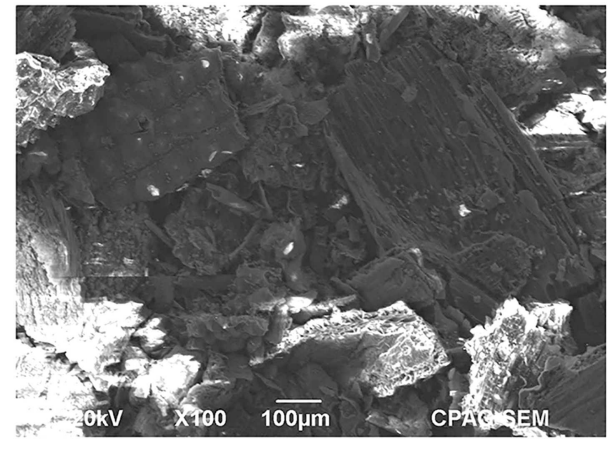

(a)

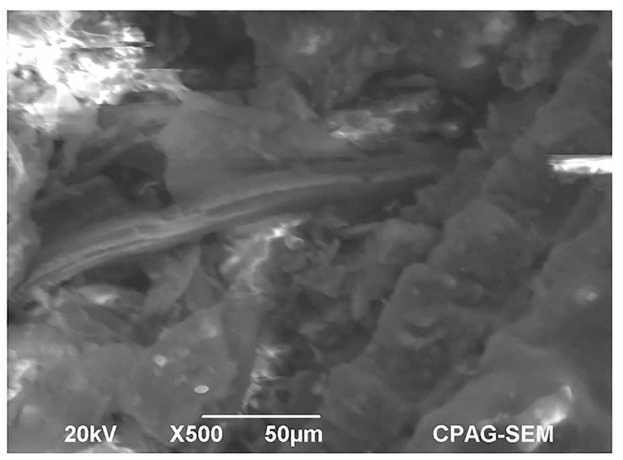

(c)

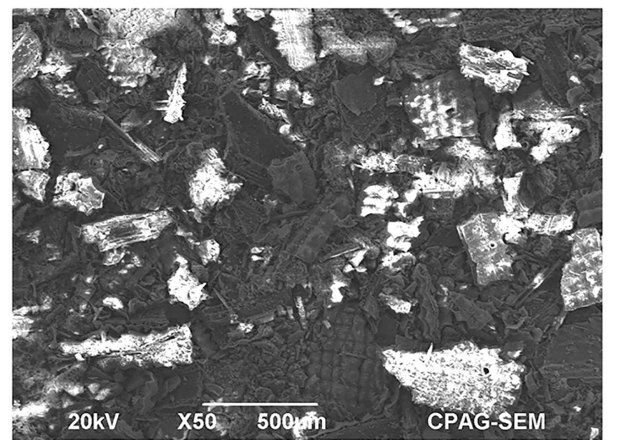

(b)

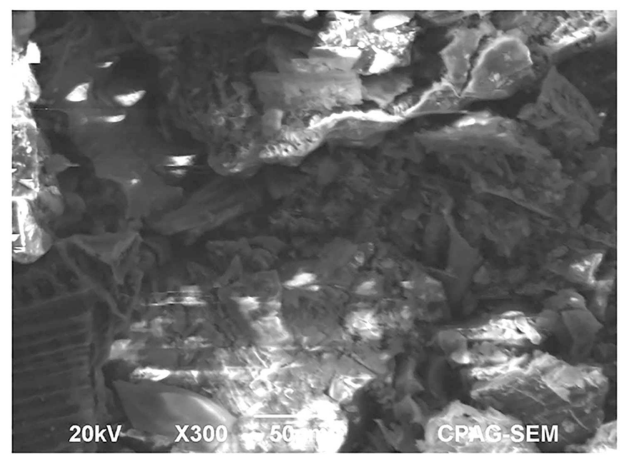

(d)

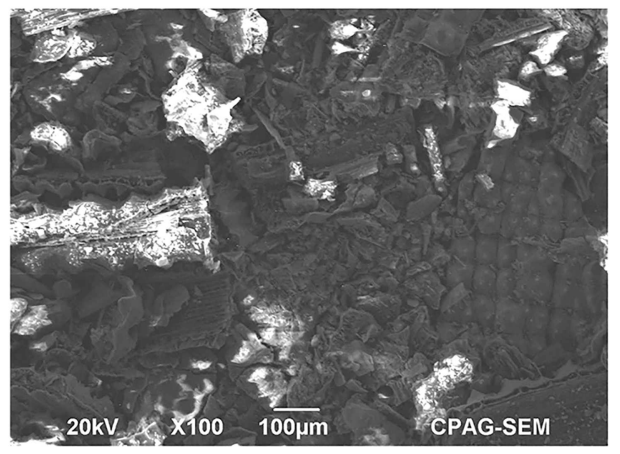

(e)

Figure 1. (a) SEM image @ $20 \mathrm{kV} \times 100100 \mu \mathrm{m}$ of RHA particles. (b) SEM image @ $20 \mathrm{kV} \times 100500 \mu \mathrm{m}$ of RHA particles. (c) SEM image @ $20 \mathrm{kV} \times 50050 \mu \mathrm{m}$ of RHA particles. (d) SEM image@ $20 \mathrm{kV} \times 30050 \mu \mathrm{m}$ of RHA particles. (e) SEM image@ $20 \mathrm{kV} \times 100100 \mu \mathrm{m}$ of RHA particles.

development of secondary Calcium Silicate Hydrated (CSH) gel due to the supplementary cementing material, which is thinner than that of the primary (CSH) gel formed by the cement. The second reason is that ash is one of the water absorption materials in nature and when it blends with concrete, it leaves interconnected voids in the concrete. Figure 4 shows that when polymer re-dispersible powder is added to the rice husk ash-modified concrete, a reduction in the water absorption capacity of the concrete is noticed. This is because lager pores are filled and blocked by the cement modifier or sealed by the continuous polymer films that give rise to the higher connectivity of the porous network, compared to non-modified mortar [11,24], thereby forming a network structure with finer porosity. Moreover, polymer is deemed to be a water-impermeable material that is dispersed in the pores of the concrete, resulting in blocking the penetration of water into interconnected voids [11]. As shown in Figure 4, the water absorption capacity of RHAMM is $4.1 \%$ with a $43.36 \%$ increase from the CM. The increasing water absorption capacity of rice husk ash-modified mix is primarily due to its density reduction. The decreasing trend of density of RHAMM illustrates that the quality of the mix in terms of porosity is affected due to the addition of RHA and, thus, the decreased density reduces impermeability. Furthermore, the water-absorbing capacity of RHAMM is reduced with the further addition of re-dispersible polymer powder. With the addition of $7.5 \%$ of RPP 


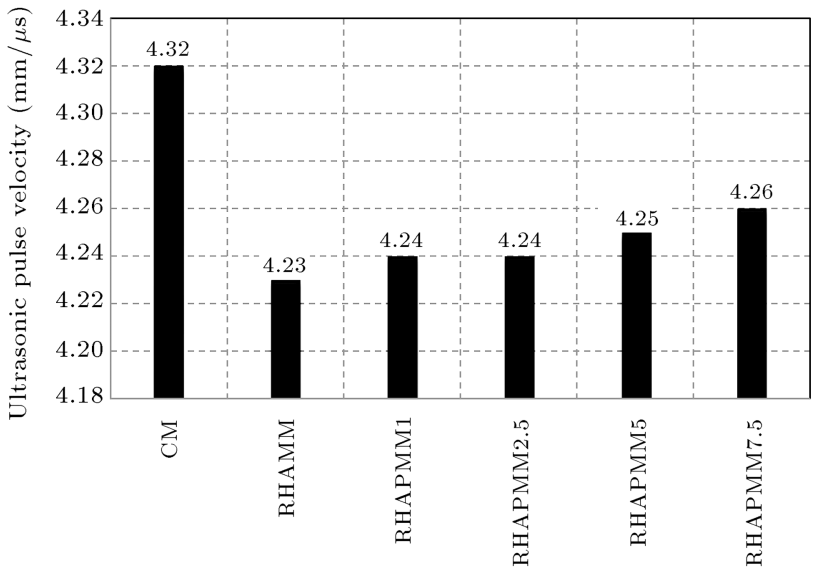

Figure 2. Ultrasonic Pulse Velocity (UPV) of Control Mix (CM), Rice Husk Ash-Modified Mix (RHAMM), and Rice Husk Ash Polymer Modified Mix (RHAPMM).

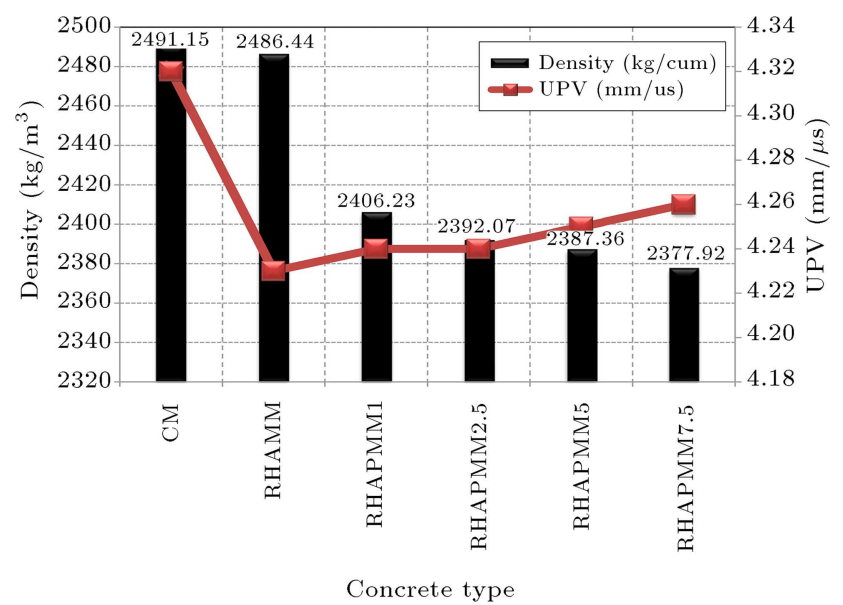

Figure 3. Density and Ultrasonic Pulse Velocity (UPV) of Control Mix (CM), Rice Husk Ash-Modified Mix (RHAMM), and Rice Husk Ash Polymer Modified Mix (RHAPMM).

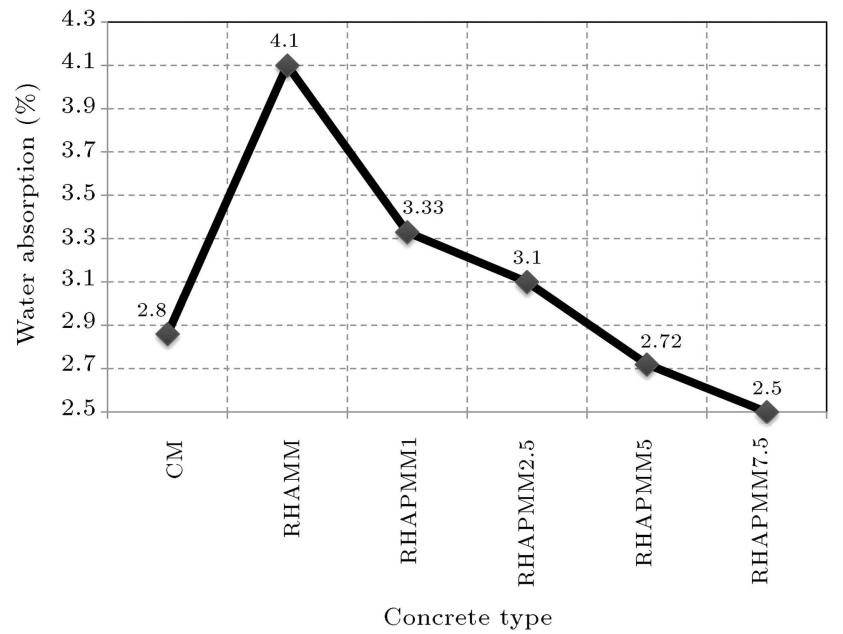

Figure 4. Water absorption capacity of Control Mix (CM), Rice Husk Ash-Modified Mix (RHAMM), and Rice Husk Ash Polymer Modified Mix (RHAPMM). to the RHA-modified concrete, the maximum water absorption capacity is $2.5 \%$ (12.59\% less), as compared to the control concrete mix. It is implied that the quality of concrete has improved with the inclusion of RPP.

\subsection{Water permeability}

Water penetration results of all mixes are shown in Figure 5. The figure shows a plot of water penetration depth of CM $10 \%$ cement replaced with RHAMM, and RHAPMC. The permeability of RHAMM has increased more than that of the CM because RHA is more water absorbent in nature. Ash requires much water for mixing in the case of concrete and mortar mixes. At the hardened stage, when water dries out, it leaves a porous medium in the concrete, thereby forming a concrete of lower density. By incorporating more quantities of polymer in the RHA concrete, the impermeability of all the mixes increases. On the one hand, the total porosity of the concrete increased with the addition of RPP due to the entrained air generated in the mixing process; on the other hand, the open porosity of the concrete decreased and caused a reduction in the permeability of concrete $[25,26]$. As shown in Figure 5, the permeability of RHAMM increases by about $30 \%$, compared to that of the CM. The increasing permeability trend of husk ash-modified mix illustrates that the porosity of RHA mix is affected by the substitution of the cement with the ash; thus, the reduced density causes decreasing impermeability. A remarkable increase in the water impermeability of the RHAMM due to the addition of varying percentage dosages of RPP has been observed. At 7.5\% dosage of RPP, the RHAMM becomes more impermeable with the increase of about 15 and $34 \%$ water impermeability than that of control and RHAMM. This is because the impermeability of the modified mixes increases due to the fact that the polymer has the pore-filling and

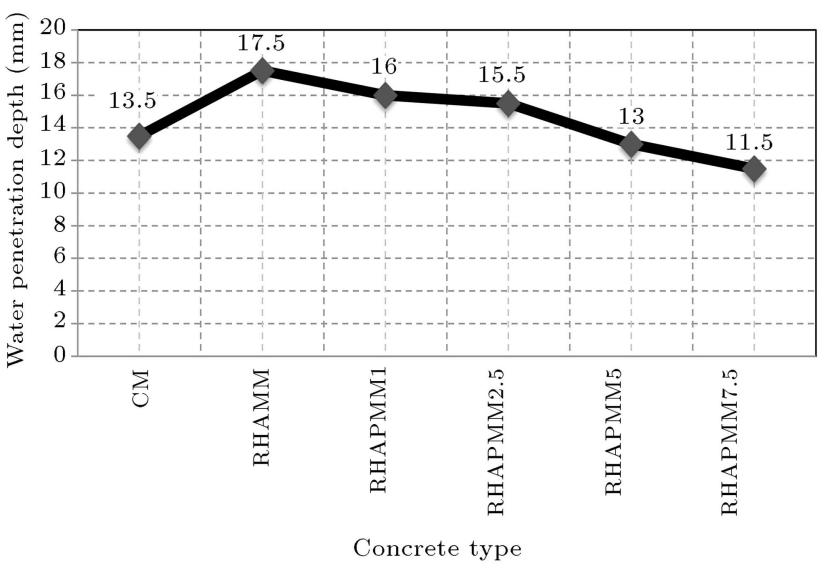

Figure 5. Water Permeability of Control Mix (CM), Rice Husk Ash-Modified Mix (RHAMM) and Rice Husk Ash Polymer Modified Mix (RHAPMM). 


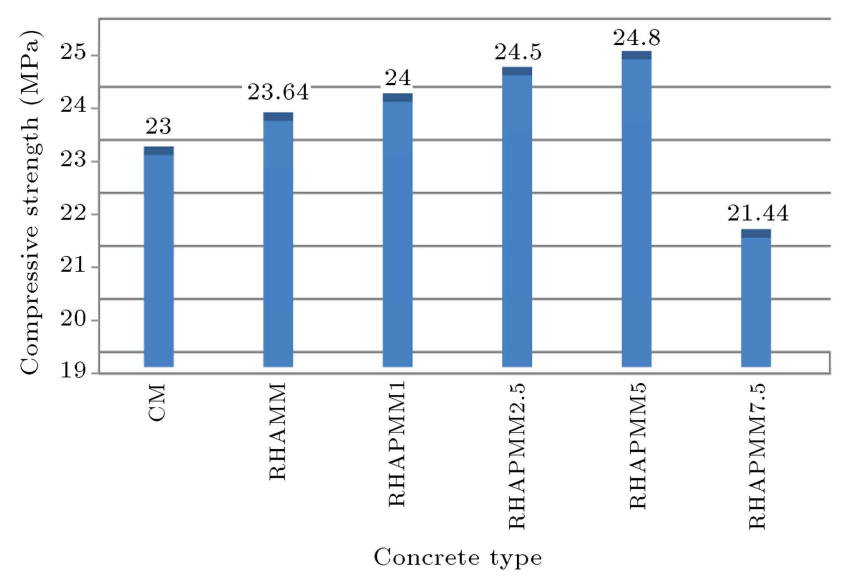

Figure 6. Compressive strength of Control Mix (CM), Rice Husk Ash-Modified Mix (RHAMM) and Rice Husk Ash Polymer-Modified Mix (RHAPMM).

sealing effect properties; these findings are also ratified by Ohama [27] and Kardon [28].

\subsection{Compressive strength}

The mean cylindrical compressive strength results of the CM, modified mix cast with the replacement of cement with $10 \%$ of RHA, and polymer-modified concrete specimens with a dosage of $1-7.5 \%$ are shown in Figure 6. Compressive strength of concrete at a $10 \%$ cement replacement level with RHA is $23.64 \mathrm{MPa}$, which is $2.78 \%$ higher than that of control concrete. By adding polymer dosages to RHA-modified concrete, the results show a slight increase in compressive strength up to $5 \%$ inclusion of the polymer. However, the compressive strength decreases with the further addition of polymer dosage. Maximum compressive strength obtained at $10 \%$ cement replacement with RHA with $5 \%$ addition of re-dispersible polymer powder is 24.8 $\mathrm{MPa}$, which is $7.83 \%$ more than the CM. An increase in the compressive strength of the polymer-modified concrete is attributed to the pore-filling ability of the polymer, and these findings are supported by the references [29-32].

\section{Conclusions}

This paper put forward a newly conceived technique for improving the durability of rice husk ash-blended concrete by incorporating Re-dispersible Polymer Power (RPP). The main conclusions drawn from this study are given below:

- The ultrasonic pulse velocity of the RHAPMC ranges from 4.24 to $4.26 \mathrm{~mm} / \mu \mathrm{s}$ and that range falls within the prescribed limit, i.e., $3.660-4.575 \mathrm{~mm} / \mu \mathrm{s}$. This range demarcates the quality of RHAPMC as an excellent one;

- Density of all RHAPMC mixes (with the inclusion of RPP from 1 to $7.5 \%$ ) was found to be lower than that of control and rice husk ash-blended concrete; however, the density of RHAPMC falls within the range of normal weight concrete;

- A 7.5\% RPP dosage added to rice husk ash concrete could be considered as the optimum mix where the maximum reduction in water absorption was $2.5 \%$, which is about $13 \%$ and $39 \%$ less than that of control mix and rice husk ash concrete, respectively;

- The lowest water penetration depth was found to be $11.5 \mathrm{~mm}$ at a $7.5 \%$ dosage of RPP, which was $15 \%$ and $34 \%$ less than that of control concrete and rice husk ash blended concrete, respectively;

- With the addition of RPP dosages of 1 to $5 \%$, the compressive strength of RHAPMC increased to a greater degree than that of the control mix; then, with the further addition of RPP, the compressive strength reduced.

\section{Acknowledgement}

The authors express thanks to Civil Engineering Department QUEST Nawabshah for providing necessary support to conduct this study.

\section{References}

1. Shetty, M., Concrete Technology, S. Chand Publishing (2005).

2. Zerbino, R., Giaccio, G., and Isaia, G.C. "Concrete incorporating rice-husk ash without processing", Constr. Build. Mater., 25(1), pp. 371-378 (2011).

3. FAO. "Production international trade rice utilization and domestic prices", Rice Market Monitor, XIX(3), pp. 1-18 (2016).

4. Fernandes, I.J., Calheiro, D., Kieling, A.G., Moraes, C.A., Rocha, T.L., Brehm, F.A., and Modolo, R.C. "Characterization of rice husk ash produced using different biomass combustion techniques for energy", Fuel, 165, pp. 351-359 (2016).

5. Fernandes, I.J., Sánchez, F.A., Jurado, J.R., Kieling, A.G., Rocha, T.L., Moraes, C.A., and Sousa, V.C. "Physical, chemical and electric characterization of thermally treated rice husk ash and its potential application as ceramic raw material", Adv. Powder Technol., 28(4), pp. 1228-1236 (2017).

6. Sandhu, R.K. and Siddique, R. "Influence of rice husk ash (RHA) on the properties of self-compacting concrete: A review", Constr. Build. Mater., 153, pp. 751-764 (2017).

7. Xu, W., Lo, T.Y., and Memon, S.A. "Microstructure and reactivity of rich husk ash", Constr. Build. Mater., 29, pp. 541-547 (2012).

8. Mehta, P.K. "Rice husk ash-a unique supplementary cementing material", Adv. Concr. Technol., pp. 419443 (1994). 
9. Habeeb, G.A. and Mahmud, H.B. "Study on properties of rice husk ash and its use as cement replacement material", Mater. Res., 13(2), pp. 185-190 (2010).

10. Giustozzi, F. "Polymer-modified pervious concrete for durable and sustainable transportation infrastructures", Constr. Build. Mater., 111, pp. 502-512 (2016).

11. Ohama, Y. "Principle of latex modification and some typical properties of latex-modified mortars and concretes adhesion; binders (materials); bond (paste to aggregate); carbonation; chlorides; curing; diffusion", Mater. J., 84(6), pp. 511-518 (1987).

12. Saand, A., Bangwar, D.K., and Kerio, M.A. "Development of polymer modified rice husk ash concrete (pmrhac)", Adv. Mater. Res., 1129, pp. 500-507 (2015).

13. Shokrieh, M.M., Rezvani, S., and Mosalmani, R. "Mechanical behavior of polyester polymer concrete under low strain rate loading conditions", Polym. Test., 63, pp. 596-604 (2017).

14. Ramli, M. and Tabassi, A.A. "Effects of polymer modification on the permeability of cement mortars under different curing conditions: A correlational study that includes pore distributions, water absorption and compressive strength", Constr. Build. Mater., 28(1), pp. 561-570 (2012).

15. ASTM C192 / C192M-16a. "Standard practice for making and curing concrete test specimens in the laboratory", ASTM International, West Conshohocken, PA (2016).

16. JIS A1171:2000, Test Methods for Polymer-Modified Mortar, Japanese Industrial Standards (2000).

17. ASTM C597-16 "Standard test method for pulse velocity through concrete", ASTM International, West Conshohocken, PA (2016).

18. C1754M-12, A.S.f.T.a.M.A.A.C., Standard Test Method for Density and Void Content of Hardened Pervious Concrete, ASTM: West Conshohocken, PA, USA (2012).

19. ASTM C1585-13. "Standard test method for measurement of rate of absorption of water by hydrauliccement concretes", ASTM International, West Conshohocken, PA (2013).

20. BS EN 12390-8:, Testing Hardened Concrete-Part 8: Depth of Penetration of Water under Pressure, London, UK (2009).

21. Rao, S.K., Sravana, P., and Rao, T.C. "Experimental studies in ultrasonic pulse velocity of roller compacted concrete pavement containing fly ash and M-sand", Int. J. Pav. Res. and Technol., 9(4), pp. 289-301 (2016).
22. Monteny, J., De Belie, N., Vincke, E., Verstraete, W., and Taerwe, L. "Chemical and microbiological tests to simulate sulfuric acid corrosion of polymer-modified concrete", Cement and Concrete Research, 31(9), pp. 1359-1365 (2001).

23. Monteny, J., et al., "Chemical and microbiological tests to simulate sulfuric acid corrosion of polymermodified concrete", Cement. Concrete Res., 31(9), pp. 1359-1365 (2001).

24. Neville, A.M., Properties of Concrete, Pearson Education (2012).

25. Bourguiba, A., Ghorbel, E., Cristofol, L., and Dhaoui, W. "Effects of recycled sand on the properties and durability of polymer and cement based mortars", Constr. Build. Mater., 153, pp. 44-54 (2017).

26. Ray, I., Gupta, A.P., and Biswas, M. "Effect of latex and superplasticiser on Portland cement mortar in the hardened state", Cement. Concrete. Comp., 17(1), pp. 9-21 (1995).

27. Shaker, F.A., El-Dieb, A.S., and Reda, M.M. "Durability of styrene-butadiene latex modified concrete", Cement. Concrete. Res., 27(5), pp. 711-720 (1997).

28. Ohama, Y., Handbook of Polymer-Modified Concrete and Mortars: Properties and Process Technology, William Andrew (1995).

29. Kardon, J.B. "Polymer-modified concrete: review", $J$. Mate. Civil Eng., 9(2), pp. 85-92 (1997).

30. Saand, A., Bangwar, D.K., and Kerio, M.A. "Development of polymer modified rice husk ash concrete (PMRHAC)", Adv. Mater. Res., 1129, pp. 500-507 (2015).

31. Susilorini, R.M.R., Hardjasaputra, H., Tudjono, S., Hapsari, G., Wahyu, S.R., Hadikusumo, G., and Sucipto, J. "The advantage of natural polymer modified mortar with seaweed: green construction material innovation for sustainable concrete", Procedia Eng., 95, pp. 419-425 (2014).

32. Ariffin, N.F., Hussin, M.W., Sam, A.R.M., Bhutta, M.A.R., Khalid, N.H.A., and Mirza, J. "Strength properties and molecular composition of epoxy-modified mortars", Constr. Build. Mater., 94, pp. 315-322 (2015).

\section{Biographies}

Daddan Khan Bangwar worked in different government organizations as a construction engineer and an assistant manager for civil projects. He has been working as an Assistant Professor at the Civil Engineering Department of Quaid-e-Awam University of Engineering, Science \& Technology since 2010. He did his Bachelor in Civil Engineering in 2001 from Muet Jamshoro, his Master in Engineering in 2011 in the field of Structural Engineering from NED Karachi, and his Doctor of Philosophy (PhD) in 2016 from QUEST Nawabshah. His research interests include structural engineering, 
concrete and mortar, supplementary cementing materials, and polymer-modified concrete and mortars.

Abdullah Saand is a Professor at the Department of Civil Engineering, Quaid-e-Awam University of Engineering, Science, and Technology, Nawabshah, Pakistan. He received his ME degree in Structural Engineering from Mehran University of Engineering and Technology, Jamshoro, Pakistan and PhD in 2007 from University of Technology Malaysia. His research interests include modified concrete, Polymer Modified Concrete (PMC), Polymer Modified Ferro Concrete (PMFC), concrete/construction material properties, and concrete repair.

Manthar Ali Keerio worked in governmental organizations as an assistant executive engineer. He has been working as an Assistant Professor at the Civil Engineering Department at Quaid-e-Awam University College of Engineering, Science \& Technology Larkano since 2011. He did his Bachelor's degree in Civil Engineering in 2004 from QUEST Nawabshah, his Master's in Engineering in 2012 in the field Hydraulics and irrigation from MUET Jamshoro, and his Doctor of Philosophy (PhD) in 2017 from QUEST Nawabshah. His research interests include irrigation engineering, concrete and mortar, supplementary cementing materials, and self-consolidating concrete.

Muhammad Auchar Zardari received his $\mathrm{PhD}$ from Lulea University of Technology, Lulea, Sweden in 2013 in Soil Mechanics and Foundation Engineering. Presently, he is an Assistant Professor at the Department of Civil Engineering, Quaid-e-Awam University of Engineering, Science, and Technology, Nawabshah, Pakistan. His research interests include numerical modeling of geotechnical structures, long-term stability of embankment dams, internal erosion of dams, geotechnical properties of waterlogged soils, and soil stabilization. 